\title{
Traffic Modeling and Simulation on the Norra Promenaden- Packhusgatan Intersection, Sweden
}

\author{
Sara Wibawaning Respati, ST.,M.Sc \\ Jurusan Teknik Sipil \\ Politeknik Negeri Balikpapan \\ J1. Soekarno Hatta KM. 8 Balikpapan \\ email: sara.wibawaning@poltekba.ac.id
}

\begin{abstract}
In this paper, the roundabout between Norra Promenaden and Packhusgatanin Norrkoping city, Sweden was studied and simulated. Afternoon rush hours (from 15:45 to 17:00) data such as the number of vehicles, travel time and queue lengths were observed. An AIMSUN model using those data was built to simulate the traffic at the roundabout intersection. This model was calibrated using travel times and queue lengths in each direction of the intersection and validated using travel time passing through the intersection. After obtaining a calibrated and validated simulation model of the real traffic, three improvements alternatives were introduced and analyzed. The first alternative is making two new free right turn ways, the second alternative is constructing an underpass from North to South direction and the third alternative is a bowtie intersection. The results show the decrease in travel time passing the intersection from all alternatives. However, each alternative has its own different impact on the local traffic and strengths/weaknesses which makes them favorable for different situations.
\end{abstract}

Keywords: Norrkoping, AIMSUN, roundabout, traffic simulation, traffic modeling

\begin{abstract}
Abstrak
Dalam penelitian ini, bundaran yang terletak pada jalan Norra Promenaden dan Packhusgatanin di kota Norrkoping, Swedia, diteliti dan disimulasikan. Data pada jam sibuk (15:45-17:00), yaitu data jumlah kendaraan, waktu tempuh dan panjang antrian diobservasi. Pemodelan dengan AIMSUN dibuat untuk mensimulasikan lalu lintas di bundaran. Model dikalibrasikan menggunakan data waktu tempuh dan panjang antrian untuk setiap lengan dan divalidasikan menggunakan data waktu tempuh melintasi bundaran. Setelah mendapatkan model yang baik, perbaikan simpang dengan tiga alternatif dilakukan dan dianalisis. Alternatif pertama adalah membuat sistem belok kanan langsung untuk dua lengan, kedua adalah membangun terowongan, dan ketiga adalah membuat bowtie intersection. Hasil simulasi menunjukkan penurunan waktu tempuh kendaraan melewati bundaran. Bagaimanapun setiap alternative memiliki dampak yang berbeda serta keunggulan dan kekurangan masing-masing yang membuat setiap alternatif tepat untuk keadaan yang berbeda.
\end{abstract}

Kata Kunci : Norrkoping, AIMSUN, bundaran, simulasi lalu-lintas, pemodelan lalu-lintas

\section{Introduction}

Traffic simulation is a powerful tool for traffic professionals to study the current traffic states and the impact of proposed changes to the future situation.

The roundabout intersection between Norra Promenaden and Packhusgatan in Norrkoping is heavily congested during rush hours, especially in the northbound and southbound direction. The nearby industrial area Saltängen brings a large number of heavy goods vehicles such as trucks and lorries. Hence, identify and solve the problem in this intersection is an essential need for transports related agencies in Norrkoping.

The project's goals are to set up, calibrate and validate a simulation model 
of a current traffic at the Norra Promenaden/Packhusgatan with AIMSUN. Three different types of observed data such as the queue lengths, travel time in a approaching leg and inside the intersection will be used.

Three alternatives for improvements on the studied intersection will be also provided and proved using AIMSUN models

\section{Data Collection}

To build the simulation model, data have to be collected first. This is an important step in this project since it influence the quality ofthe AIMSUN model as well as the calibration, validation and improvement in the later part.

In this project, traffic flow is measured as the input of an OD-matrix for the roundabout. For the type of data used for calibration, travel time in legs as well as queue length in legs is used. For the type of data used for validation, travel time in roundabout is chosen.

\section{I.1. 2.1. Traffic flow}

During the collection of traffic flows, the flow was measured every 15 minutes in weekdays. After observing the traffic flow for two days, the data shows that from 15:45 to 17:00, the traffic flows for each leg in each 15 minutes were very high compared to other time period. Hence, the peak hours have been identified to be from 15:45 to 17:00 in weekdays.

The method used to measure the traffic flow is as follows. First of all, the type of vehicle is separated into four categories: car, bus, truck and lorry. Secondly, the turning proportion of each leg is divided into three directions: go straight, turning right and turning left. Each leg was measured five times and the mean value of traffic flows were calculated for the OD matrix creation as the input data for the Aimsun model.

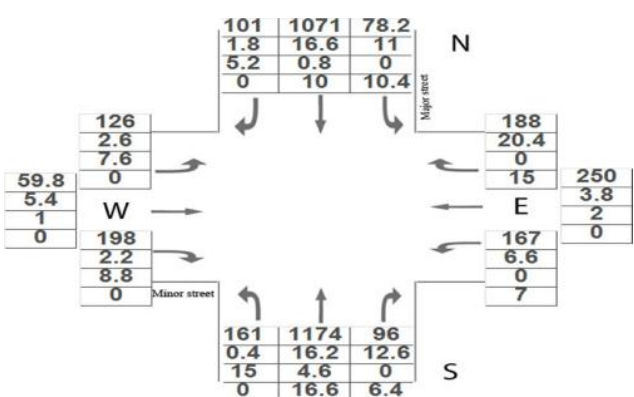

Fig. 1 Mean traffic flow from $15: 45$ to $17: 00$ in

number of vehicles.

At each turn, the first row represents the number of cars, the second trucks, third buses, and the fourth row number of Lorries.

\subsection{Travel time in legs}

From the AIMSUN Output Database Definition [1], there are several types of data can be easily measured. Travel time is one of them. In order to do the calibration and validation with different type of data, travel time in legs is chosen to be the data for calibration and travel time passing roundabout is chosen to be the data for validation.

The method to measure the travel time is shown in figure 2 , with an example of observing in the West part.

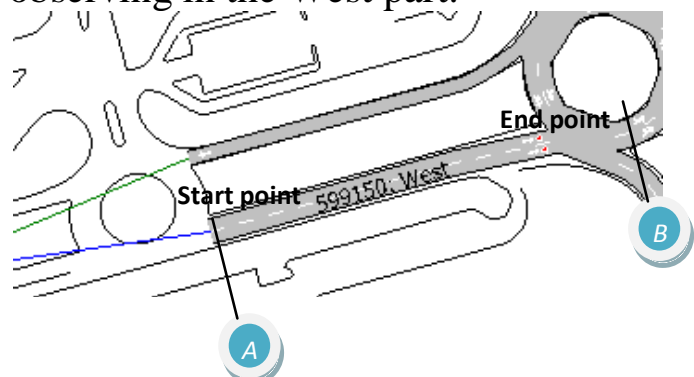

Fig. 2 Measurement method of traffic time in legs

A long ruler is used to measure 100 meters for each legs starting from the give way sign, which is at the border of legs and roundabout. Every 1.5 minutes, a car is chosen randomly at the start point with its head passing the point, and it is noted at the end point. 
Table 1 Measurement Result of Travel Time In Legs (Secs)

\begin{tabular}{|c|ccc|}
\hline South & West & East & North \\
\hline 19.22987 & 30.17067 & 41.85147 & 29.77407 \\
\hline
\end{tabular}

As can be seen from the measurement, the travel time in the Eastbound is longest while that of Southbound is shortest.

\subsection{Queue length}

Except for travel time, queue length is also used to make the calibration more accurate. Besides, queue length is the best data to describe traffic congestion which match the project goal very well. By calibrating queue length, the best

improvement for this roundabout can be easily find out.

Queue length was measured at the same time when measuring travel time in legs. Since it is hard to measure the queue length by meters, number of cars is chosen to be the unit of this data. Every 1 minute, the number of cars in the queue for two lanes is counted, with the start point to be the give way sign. Therefore, there are totally 6 days for queue length measurement and 3 times for each leg. For each time, the time period is from 15:45 to 17:00. The mean value is shown in Table 5 .

TABLE 2 Measurement Result Of Queue Length (Cars)

\begin{tabular}{|c|ccc|}
\hline South & West & East & North \\
\hline 3.835556 & 2.171111 & 4.1 & 6.468889 \\
\hline
\end{tabular}

As can be seen from the table, the Northbound has the longest queue length while the Westbound has the shortest queue length.

\subsection{Travel time passing roundabout}

To make sure the AIMSUN model is close to the real condition and that it is a good model, a different type of data is chosen. That is the travel time of a car passing through a leg to the opposite leg - travel time passing roundabout.

Every 1.5 minutes, the travel time is measured once using the same method used in measuring travel time in legs, because the travel time which need to be measured is from the beginning of a section to the beginning of the opposite section. The value is shown in the table below.

TABLE 3 Measurement Result Of Travel Time In Roundabout (Secs)

\begin{tabular}{|cccc|}
\hline S-N & W-E & E-W & N-S \\
\hline 28.4446 & 44.328 & 56.0218 & 45.348 \\
\hline
\end{tabular}

As can be seen from the table above, the travel time from west to east, east to west and north to south is similar, but that from south to north is much smaller than the others.

\section{The Simulation Model}

\subsection{Network layout}

The model is built at the same time with data collection. To draw the network more close to the real infrastructure, the figure of Norra Promenaden/Packhusgatan roundabout was imported from one map of GIS laboratory, so that the drawing process is more accurate. Following the shape from the GIS map, the roundabout and four legs were drawn. For the west, east and south legs, they are defined to be 100 meters long. For the north leg, it is define it to be 96 meters, since the travel time in legs were measured with 96 meters for that part. One more difference is that the west part was drawn to be a unite section, which means the island between two lanes was ignored. The 
reason for that is because the total travel time for the whole westbound is needed, while the model works mostly the same in AIMSUN model as in reality. The maximum speed of each leg is set to be $50 \mathrm{~km} / \mathrm{h}$, according to the observation as well as normal knowledge. After drawing the sections, nodes were used to connect them, according to the real traffic direction. Since vehicles in the roundabout have higher priority than those in the legs, the give way sign were set for each leg. Finally, the traffic demand centroid for each direction was drawn.

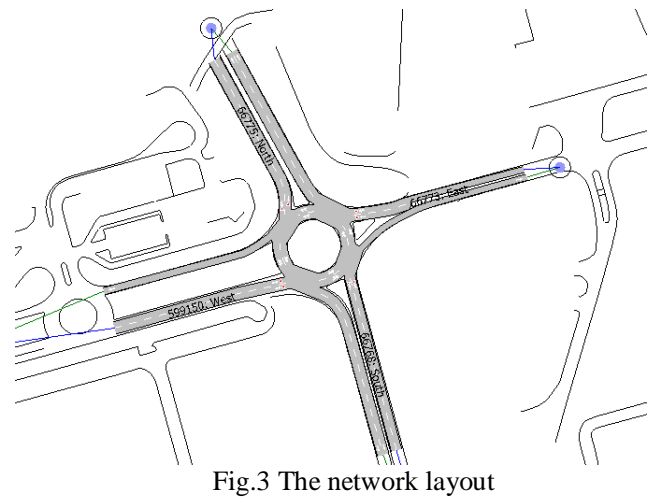

Now the traffic demand data should be inputted. Since there are no traffic lights, the traffic control plan is not used. The first data input is OD-Matrices.

The second step is to set up the parameters for 4 kinds of vehicles. At present, only the original value for each kind of vehicle is set, then set their parameters in AIMSUN model. Traffic matrix is chosen is this paper.

\subsection{Modeling Generation}

Before doing the calibration, which kind of arrival distribution will be used needs to be decided. When loading traffic demand into AIMSUN model, a headway modelneeds to be chosen, in which the headway is sampled from a random distribution. From the AIMSUN manual [1], there are totally five headway models. They are exponential, uniform, normal, constant, "ASAP" and external.

AIMSUN Manual [1] says: "Exponential model is that the headway at input sections are sampled from an exponential distribution. Uniform model is that headway at input sections are sampled from a uniform distribution. Normal model is that the headway at input sections are sampled from a truncated normal distribution. Constant model is that the headway at input sections are always constant." "ASAP" model is that vehicles who want to enter the network always enter as soon as possible. External model is used only in AIMSUN MICRO, which does not generate vehiclesor input data into the network via any section by the simulator itself [1].

According the definitions for each model above, and comparing the real traffic condtition, it is obvious that the traffic flow for Norra Promenaden and Packhusgatan roundabout is not uniform or constant. Since the input as well as output data are needed from the simulator, external model is eliminated, either. From the Swedish driving habits, it is impossible for them to enter the network as soon as possible. By observation, the group members find that there is a traffic light in the south part before entering the network. What is more, a small roundabout near the bus station in the west part also influences the traffic flow. To sum up, exponential model is chosen.

\section{Calibration}

Model calibration is a process to adjust the parameter in the model in order to have a similar result between model output and observed data. According to the literature [2], there is no exact number of replications that must be done. The most common number of 
replication is between 5 to 10 replications. This study uses 10 replications in the experiment.

The vehicle global parameters are used in AIMSUN[1]. The following parameters are adjusted in the calibration process. Some of the parameters are set once and keep their value the same until the calibration is finished i.e: Vehicle length , Car width , Minimum distance vehicle and Sensitivity factor.

The step for the calibration process is explained below. Assume that $\mathrm{x}$ is the array of the observation data and $y$ is the array for the simulation result. To decide whether the observed data is the same with the simulated data or not, we compare $\mu_{x}$ and $\mu_{y}$ with hypothesis: $H_{o}: \mu_{x}=\mu_{y} ; H_{1}: \mu_{x} \neq \mu_{y}$

If $|\mathrm{T}|<\mathrm{t}_{\mathrm{n}_{\mathrm{x}}+\mathrm{n}_{\mathrm{y}-2}\left(\frac{\alpha}{2}\right)}$ the hypothesis $\mathrm{H}_{\mathrm{o}}: \mu_{\mathrm{x}}=\mu_{\mathrm{y}}$ cannot be rejected, otherwise the calibration process will be continued by adjusting parameter until the value of $|\mathrm{T}|$ is satisfied.

Thet $_{\mathrm{n}_{\mathrm{x}}+\mathrm{n}_{\mathrm{y}-2}}\left(\frac{\alpha}{2}\right)$ value is t-table[3]with degrees of freedom value $n_{x}+n_{y}-2$, where $n_{x}$ is the number of observed data and $n_{y}$ is the number of simulation data.

$$
\begin{gathered}
T=\frac{\bar{X}_{x}-\bar{X}_{y}}{S_{p}} \sqrt{\frac{n_{x} \cdot n_{y}}{n_{x}+n_{y}}} \\
S^{2}{ }_{p}=\frac{\left(n_{x}-1\right) S^{2}{ }_{x}+\left(n_{y}-1\right) S^{2}{ }_{y}}{n_{x}+n_{y}-2}
\end{gathered}
$$

Where $n_{x}$ is the number of observed data and $\mathrm{n}_{\mathrm{y}}$ is the number of simulation data. The calibration in this model uses the confidence level of $95 \% \quad(\alpha=0.05)$. Thet $_{n_{x}+n_{y-2}}\left(\frac{\alpha}{2}\right)$ value is obtained from the t-table [3]. The car travel time of the simulation described below is the average value of ten replications.
TABLE 4 Travel Time In The Section (Secs)

\begin{tabular}{|cccc|}
\hline West & North & East & South \\
\hline 30.17 & 29.77 & 41.85 & 19.23 \\
\hline
\end{tabular}

The average value of queue length observed in the animated simulation every 1 minute is shown in the table 8 below.

TABLE 5 Queue Length Result (Cars)

\begin{tabular}{|cccc|}
\hline West & North & East & South \\
\hline 2.17 & 8.47 & 4.10 & 3.84 \\
\hline
\end{tabular}

The car travel time in the roundabout is used as the validation data. The result from the model is:

TABLE 6 Travel Time Inside Roundabout (Secs)

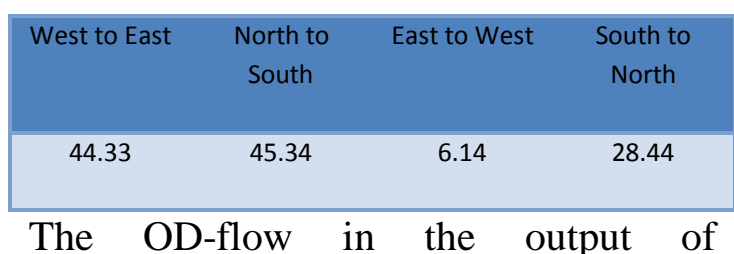

AIMSUNis checked to ensure that the model has the same OD-flow as the input does. The $t_{n_{x}+n_{y-2}}\left(\frac{\alpha}{2}\right)$ value for travel time is 2.0018 with $\mathrm{n}_{\mathrm{x}=50 \text { and }}$ $\mathrm{n}_{\mathrm{y}=10}$. The calculation result is:

TABLE 7 Calibration Result

\begin{tabular}{|ccccc|}
\hline |T $\mid$ & 1.1802 & 0.55 & 0.414 & 1.1802 \\
\hline t-table & 2.0018 & 2.0018 & 2.0018 & 2.0018 \\
\hline valid & yes & yes & yes & yes \\
& & & & \\
\hline
\end{tabular}

The table above concludes that $|\mathrm{T}|<$ $\mathrm{t}_{\mathrm{n}_{\mathrm{x}}+\mathrm{n}_{\mathrm{y}-2}\left(\frac{\alpha}{2}\right)}$, since it satisfies the constraint, so the hypothesis $\mathrm{H}_{\mathrm{o}}: \mu_{\mathrm{x}}=\mu_{\mathrm{y}}$ cannot be rejected.

The second type of data used in the calibration process is queue length. The observed queue length is collected 
every 1 minute in two lanes; the same method to collect the simulated queue length is used. The model is simulated and the number of car in queue is observed every 1 minute. The same process as calibrate the travel time also applied here. The hypothesis $\mathrm{H}_{0}: \mu_{\mathrm{x}}=$ $\mu_{\mathrm{y}}$ cannot be rejected if $|\mathrm{T}|<$ $\mathrm{t}_{\mathrm{n}_{\mathrm{x}}+\mathrm{n}_{\mathrm{y}-2}}\left(\frac{\alpha}{2}\right)$ The $\mathrm{t}$-table result for $\mathrm{n}_{\mathrm{x}}=75$ and $\mathrm{n}_{\mathrm{y}}=75$ is 1.982827 .

TABLE 8 OBSERVED QUEUE LENGTH AND OUTPUT FROM AIMSUN MODEL (CARS)

\begin{tabular}{|cllll|}
\hline$|T|$ & 1.89811 & 1.884151 & 0.27895 & 1.77774 \\
& & & & \\
\hline t-table & 1.9828 & 1.9828 & 1.9828 & 1.9828 \\
\hline Valid & yes & yes & yes & yes \\
\hline
\end{tabular}

The $|T|$ values of the queue length calibration is smaller than t-table, $|T|<1.9828$, so the model represents the observed data accurately since the hypothesis $H_{o}: \mu_{x}=\mu_{y}$ cannot be rejected.

\section{Validation}

According to Law and Kelton, 1991 in the AIMSUN manual, validation is a process to determine whether the model built is acceptable or not. The acceptable model means that the model can represent the reality accurately. The observed data that is not used in the calibration process is used to do the validation. This project uses travel time in the roundabout to do validation. The $t_{n_{x}+n_{y-2}}\left(\frac{\alpha}{2}\right)$ value for west

is 2.0357 and for the others are 2.0018. The all $|T|$ values are smaller than 2.0357 (t-table), so that, with the 95\% level of confidence, the hypothesis of observed data similar with simulated data cannot be rejected.

\section{Improvement}

The studied intersection between Norra Promenaden and Packhusgatan in Norrkoping is heavily congested during rush hours with the current traffic control and infrastructures. Therefore, three alternatives are proposed for its improvement, including the approval of their better performance using AIMSUN. From the observed travel time on each leg, it can be seen that the travel time in the Westbound and Eastbound of the intersection is much higher than in the Northbound and Southbound, despite the fact that the flow in the two later legs are much higher.

The reason for that is because the flow in the Northbound and Southbound of the intersection is relatively large (see table number 9), so that cars in Eastbound and Westbound have to wait long until they have a gap to go. Therefore, our aim in this improvement part of the project is reduce the effect of the high traffic flow from the North and South part of the intersection.

Table 9: Total number of vehicles in each leg, from the time of observation (15:45 to $17: 00$ )

\begin{tabular}{|llll|}
\hline South & West & East & North \\
\hline 1503 & 411 & 660 & 1306 \\
\hline
\end{tabular}

The eligibility of each alternative will be compared with each other and with the original design in this part, in terms of the travel time passing the intersection.

6.1. Alternative 1: Free right turns on two legs 
While it is not possible to reduce the flow in Northbound and Southbound of the intersection, and grade-separated interchange has been also not yet mentioned (this alternative will be studied later), reducing the queue lengths in the Eastbound and Westbound is possibly a positive method. Making two free right turns on East and West part of the intersection is a practicable alternative, because of reasons:

- Firstly, it is more reasonable to make dedicated right turns in a roundabout, since going straight and turn left traffic will use the same lanes.

- Thirdly, the right turning proportion in from East and West of the intersection is relatively high, with $31.09 \%$ and $51.59 \%$, respectively (according to the mean observed data)

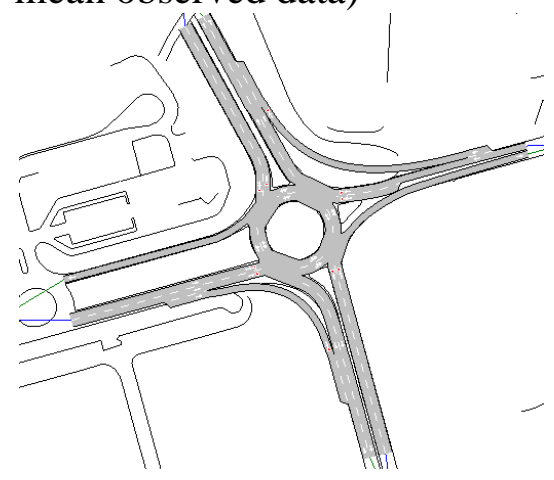

Fig.4 Free right turns alternative

After running the model with the new network layout and the same parameters as the original one, the following results has been yielded from AIMSUN.

Table 10: Comparison of travel time passing the intersection between alternative 1 and original design

\begin{tabular}{|lrrrrr|}
\hline & \multicolumn{1}{l}{$\begin{array}{l}\text { West to } \\
\text { East }\end{array}$} & $\begin{array}{l}\text { South to } \\
\text { North }\end{array}$ & \multicolumn{1}{l}{$\begin{array}{l}\text { North to } \\
\text { South }\end{array}$} & \multicolumn{2}{l}{$\begin{array}{l}\text { East to } \\
\text { West }\end{array}$} \\
\hline Original & 43.111 & 25.906 & 43.020 & 68.948 \\
\hline Alternative 1 & $\mathbf{2 5 . 7 4 9}$ & $\mathbf{2 7 . 7 3 8}$ & $\mathbf{2 4 . 3 0 9}$ & $\mathbf{5 0 . 5 6 6}$ \\
\hline Comparison & $40 \%$ & $-7 \%$ & $43 \%$ & $26 \%$ \\
\hline
\end{tabular}

As could be seen on the table, the Northbound, Westbound and Eastbound travel time passing through the intersection will be reduced if the alternative 1 is applied, especially the traffic from West and North direction. However, the travel time of the Southbound is $7 \%$ higher in the alternative 1 compared with the original design.

The test in this part uses the confidence level of $95 \% \quad(\alpha=0.05)$. $\mathrm{t}_{\mathrm{n}_{\mathrm{x}}+\mathrm{n}_{\mathrm{y}-2}}\left(\frac{\alpha}{2}\right)$ value is obtained from the $\mathrm{t}$ Table. If $|\mathrm{T}|<\mathrm{t}_{\mathrm{n}_{\mathrm{x}}+\mathrm{n}_{\mathrm{y}-2}}\left(\frac{\alpha}{2}\right)$ the hypothesis

$\mathrm{H}_{\mathrm{o}}: \mu_{\mathrm{x}}=\mu_{\mathrm{y}}$ is accepted, it means the impact of changes is significant. Ten replications of the original model will be tested with ten replications of the modified model for alternative 1 . The following table shows the testing results, with $\mathrm{x}$ is the alternative 1 travel time, $\mathrm{y}$ is the original design travel time.

Table 11: Hypothesis test of the travel time passing the intersection, alternative 1 compared to original design

\begin{tabular}{|crrrr|}
\hline & West to East & South to North & North to South & East to West \\
\hline $\mathrm{T}$ & 2.911 & -1.012 & 2.935 & 2.790 \\
\hline $\mathrm{t}$ & 2.101 & 2.101 & 2.101 & 2.101 \\
\hline & Significant & Insignificant & Significant & Significant \\
\hline
\end{tabular}

The above table shows that the improvement in the Westbound, Northbound and Eastbound of the intersection is significant, while a little worse in travel time in Southbound is insignificant for the intersection. The reason for a slightly larger in passing through travel time from South to North is because the vehicles from the East has more chance to pass, leading to much waiting time for vehicles from the South direction.

\subsection{Alternative 2: Underpass for Northbound and Southbound traffic}


As mentioned above, the biggest problem in this intersection is the large flow coming from the North and the South. Therefore, the most effective way to reduce the bad effect of these flows is building an interchange, which will allow uninterrupted movement of the flow.

The new model has the same parameters with the original one, but there are some important differences from the design. There are two underpasses with the length of 150.2 meters from North and South direction. To keep the high speed during passing through the underpass, and because the different in the elevation of lanes, vehicles must choose which lane they will follow at 100 meters from the intersection. The following table shows the simulated results.

Table 12: Comparison of travel time passing the intersection between alternative 2 and original design

\begin{tabular}{|lllll|}
\hline & $\begin{array}{l}\text { West to } \\
\text { East }\end{array}$ & $\begin{array}{l}\text { South to } \\
\text { North }\end{array}$ & $\begin{array}{l}\text { North to } \\
\text { South }\end{array}$ & $\begin{array}{l}\text { East to } \\
\text { West }\end{array}$ \\
\hline Original & 43.111 & 25.906 & 43.020 & 68.948 \\
\hline $\begin{array}{l}\text { Alternative } \\
\mathbf{2}\end{array}$ & $\mathbf{1 5 . 5 0 5}$ & 19.866 & 19.634 & 17.304 \\
\hline Comparison & $64 \%$ & $23 \%$ & $54 \%$ & $75 \%$ \\
\hline
\end{tabular}

The hypothesis testing method was once again applied to see the impact of these changes in travel time.

Table 13: Hypothesis test of the travel time passing the intersection, alternative 2 compared to original design

\begin{tabular}{|ccccc|}
\hline $\mathbf{T}$ & $\begin{array}{c}\text { West to } \\
\text { East }\end{array}$ & $\begin{array}{c}\text { South to } \\
\text { North }\end{array}$ & $\begin{array}{c}\text { North to } \\
\text { South }\end{array}$ & $\begin{array}{c}\text { East to } \\
\text { West }\end{array}$ \\
\hline $\mathbf{t}$ & 2.965 & 2.293 & 2.959 & 2.981 \\
\hline Impact & $\begin{array}{c}\text { Significan } \\
\mathrm{t}\end{array}$ & Significant & Significant & Significant \\
\hline
\end{tabular}

All the improvements in the four legs are significant. From the animated simulation of this model, there is also no long queue lengths and congestion.

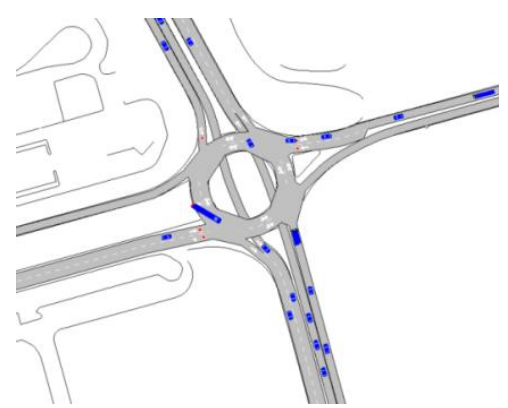

Fig.5 Underpass design - animated simulation

\subsection{Alternative 3: Bowtie intersection}

Convert the roundabout into a signalized intersection could give us more power in controlling the travel time in each leg. According to a scientific journal by Bassem Younes, signalized intersections have better performance in increased traffic demands and better traffic control in high traffic flow urban roads[4]. However, some others study believes that roundabouts offer continuous and faster traffic flow and less traffic jam than signalized intersection [5]. Roundabouts are also believed to be more safety for vehicles [6]. Especially in this intersection where the left turning proportions are relatively high, roundabouts can handle left turn traffic better than the signalized intersection [7]. It is more accurate if we could have different models of signalized intersection and roundabout to find the differences. According to the Highway Capacity Manual 2000 [8], durations of green time for each phases has been calculated for initial step, and then calibrated for the optimal set. The method for calibrating these phases isjust trial-and-error. Because the turning left proportion is high, according to the Highway Capacity Manual [8] this intersection needs 4 phases, with 2 phases for turning left traffic. 


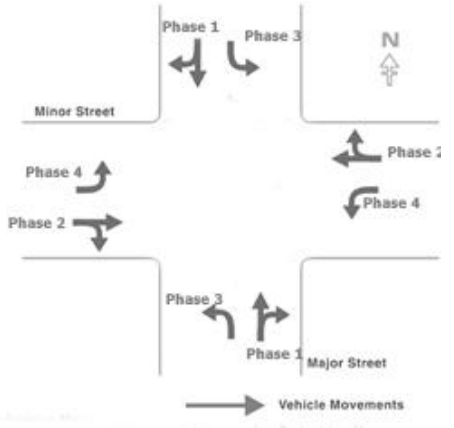

Fig.6 Four phase of the signalized design [9]

Table 14 : Duration of green time for each phases

\begin{tabular}{|ccccc|}
\hline & Phase 1 & Phase 2 & Phase 3 & Phase 4 \\
\hline Flow no. & 2 and 6 & 8 and 4 & 1 and 5 & 3 and 7 \\
\hline $\begin{array}{c}\text { Duration } \\
\text { (s) }\end{array}$ & 52 & 35 & 20 & 20 \\
\hline
\end{tabular}

The four phases are illustrated in the figure 15 and their durations are shown in the table 20 above. The yellow time is 3 seconds. After running this simulation model with 4 phases signal and the same parameters with the original design, the following travel time are produced from AIMSUN.

\begin{tabular}{|c|c|c|c|c|}
\hline & $\begin{array}{c}\text { West to } \\
\text { East }\end{array}$ & $\begin{array}{c}\text { South to } \\
\text { North }\end{array}$ & $\begin{array}{c}\text { North to } \\
\text { South }\end{array}$ & $\begin{array}{c}\text { East to } \\
\text { West }\end{array}$ \\
\hline Original & 43.111 & 25.906 & 43.020 & 68.948 \\
\hline Signalized & 72.512 & 160.723 & 137.429 & 289.767 \\
\hline Comparison & $-68 \%$ & $-520 \%$ & $-219 \%$ & $-320 \%$ \\
\hline
\end{tabular}

The travel time passing through the intersection is rocketed increased compared to the original design, especially in the Eastbound. Without the hypothesis test, it can be seen that this signalized design is not better than the original roundabout design. Therefore, the Wisconsin Department of Transportation [5] and the FHWA studies [6] are correct in this particular situation. In conclusion, the normal signalized intersection cannot be applied.

A mixed solution between the roundabout and signalized intersection is the "bowtie" intersection. The idea is using two roundabout placed at East and West direction, away from the main intersection to accommodate left turns and allow more traffic to flow comfortably through the main intersection[10]. Hence, inside the main intersection, left turning is prohibited.

The two supporting roundabout at the East and West of the intersection are not included in the model but still have their impact on the traffic. Turning left inside the intersection will be prohibited, all the turn left proportion will be added to the turn right and go straight of the adequate directions. Inside the roundabout, signalized control is used to control the traffic. A new ODmatrix created in AIMSUN. Because vehicles which want to turn left must turn right to pass through the intersection, and come back after that, there are more vehicles in the OD matrix in the duration of 1 hour and 15 minutes. This alternative needs only two phases as control phases. The green time for each phase has been calculated and calibrated with the method used in normal signalized intersection.

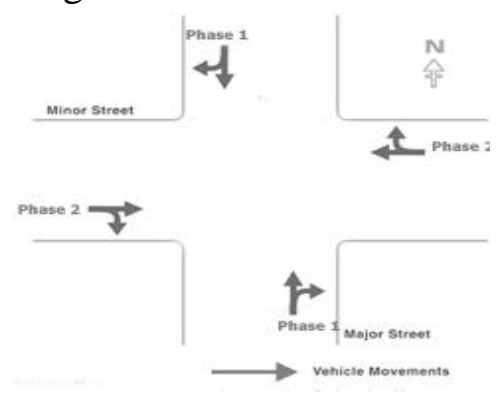

Fig. 7 The bowtie intersection signal phases 
The duration for each phase is:

Table 16 : Duration of green time for each phases

\begin{tabular}{|ccc|}
\hline Flow no. & Phase 1 & Phase 2 \\
\hline $\begin{array}{c}\text { Duration } \\
\text { (s) }\end{array}$ & 52 & 8 and 4 \\
\hline
\end{tabular}

Finally, AIMSUN provides the simulated travel time pass through the intersection

Table 17: Comparison of travel time passing the intersection between alternative 3 and original design

\begin{tabular}{|ccccc|}
\hline Original & $\begin{array}{c}\text { West to } \\
\text { East }\end{array}$ & $\begin{array}{c}\text { South to } \\
\text { North }\end{array}$ & $\begin{array}{c}\text { North to } \\
\text { South }\end{array}$ & $\begin{array}{c}\text { East to } \\
\text { West }\end{array}$ \\
\hline Alternative 3 & $\mathbf{4 4 . 3 3 5}$ & $\mathbf{3 6 . 0 0 8}$ & $\mathbf{3 6 . 8 7 1}$ & $\mathbf{5 6 . 2 1 8}$ \\
\hline Comparison & $-1 \%$ & $-39 \%$ & $30 \%$ & $27 \%$ \\
\hline
\end{tabular}

The AIMSUN results show a more equally distributed travel time between each bound of the intersection. Vehicles can travel faster from the West, North and East of the intersection, while there is a decrease in travel time of vehicles in the Southbound. The hypothesis test has been used to find the impact of these changes

Table 18: Hypothesis test of the travel time passing the intersection, alternative 3 compared to original design

\begin{tabular}{|ccc|cc|}
\hline $\mathbf{T}$ & $\begin{array}{c}\text { West to } \\
\text { East }\end{array}$ & $\begin{array}{c}\text { South to } \\
\text { North }\end{array}$ & $\begin{array}{c}\text { North to } \\
\text { South }\end{array}$ & $\begin{array}{c}\text { East to } \\
\text { West }\end{array}$ \\
\hline $\mathbf{t}$ & -0.805 & -2.671 & 2.527 & 2.586 \\
\hline $\begin{array}{c}\text { Impa } \\
\text { ct }\end{array}$ & $\begin{array}{c}\text { Insignifica } \\
\text { nt }\end{array}$ & Significant & Significant & Significant \\
\hline
\end{tabular}

The hypothesis test results indicate that while the improvement of travel time in the Northbound is significant, the increase of travel time in the Southbound is also considerable. The following results from AIMSUN model show that the study about "bowtie" intersection of the Community Planning Association of Idaho is correct in this intersection. The bowtie intersection in this situation has better performance than a single roundabout or signalized intersection.

Choosing the optimal alternative: All three alternatives have improvements for the intersection traffic and their own effects on the local traffic.

Table 19: Comparison of travel time passing the intersection between the three alternatives and the original design

\begin{tabular}{|lccc|}
\hline & Alt. 1 & Alt. 2 & Alt. 3 \\
\hline West to East & $40 \%$ & $43 \%$ & $3 \%$ \\
\hline South to North & $-7 \%$ & $22 \%$ & $-33 \%$ \\
\hline North to South & $43 \%$ & $53 \%$ & $37 \%$ \\
\hline East to West & $26 \%$ & $57 \%$ & $24 \%$ \\
\hline
\end{tabular}

In order to choose the best alternative among them, strengths and weaknesses of each design over others was studied.

Table 20 : Strengths and weaknesses of the three designs

\begin{tabular}{|c|c|c|}
\hline $\begin{array}{l}\text { Alt. } \\
\text { no. }\end{array}$ & Strengths & Weaknesses \\
\hline 1 & $\begin{array}{l}\text { +Less } \\
\text { construction } \\
\text { works, low } \\
\text { project budget }\end{array}$ & $\begin{array}{l}\text { +Must ask for permission of } \\
\text { cutting some space at the car } \\
\text { park }\end{array}$ \\
\hline $\begin{array}{l}\text { Alt. } \\
\text { no. }\end{array}$ & Strengths & Weaknesses \\
\hline 2 & $\begin{array}{l}\text { +Largest reduce } \\
\text { in travel time } \\
\text { among all }\end{array}$ & $\begin{array}{l}\text { +Large project budget needed } \\
\text { +May cause congestions in } \\
\text { nearby intersections } \\
\text { +By eliminating the turning } \\
\text { left proportions from the flow, } \\
\text { congestions and accidents can } \\
\text { be reduced inside the } \\
\text { intersection compared to the } \\
\text { signalized or one single } \\
\text { roundabout intersection }\end{array}$ \\
\hline 3 & $\begin{array}{l}\text { +Equally } \\
\text { distributed in } \\
\text { travel time, better } \\
\text { management of } \\
\text { travel time if } \\
\text { needed }\end{array}$ & $\begin{array}{l}\text { +Change in city traffic } \\
\text { management for heavy } \\
\text { vehicles - the consequences } \\
\text { are not known yet } \\
\text { +May cause congestions in the } \\
\text { two supporting roundabouts }\end{array}$ \\
\hline
\end{tabular}

In conclusion, the alternative 1 is the most applicable improvement alternative for the intersection, with its low cost, good performance and less negative effects to the local traffic. The underpass design will be the best alternatives if there are enough budgets for the project itself and funds for improving the nearby intersections. The bowtie intersection 
design is also good if traffic managers plan to implement green wave traffic control in the area.

\section{Conclusion}

This project simulates the real traffic in the weekdays afternoon rush hours at Norra Promenaden/ Packhusgatan roundabout by using an AIMSUN model. The model has been calibrated using travel time and queue lengths in each leg, and validated using travel time passing the intersection. The real traffic data such as vehicles flows, travel time and queue lengths in the roundabout were observed by the project group in afternoon rush hours $(15: 45$ to 17:00).

The two important findings of this project are firstly the simulation model of the afternoon rush hours traffic of the intersection and secondly three improvements design for this roundabouts. The first design has two new free right turns for the Eastbound and Westbound traffic, the second design is an underpass from North to South direction and the third design is a bowtie intersection. Hypothesis tests were used to study the impact of these changes to the future traffic. The effects of these alternatives to the local traffic if they are implemented as well as their strengths and weaknesses are also studied. The results show the improvement in all the three alternatives and analysis show their suitability in each particular situation. There are still some parts which need to be improved in future researches. The model should reflect the differences in traffic of different days in weekdays. Another model for morning rush hours traffic also needs to be created. In the improvement section, the detailed design of each alternative as well as their future impact needs to be studied further.

\section{Acknowledgment}

We would like to acknowledge Mr. Le Minh Kieu and Ms. Yi Qian, for their work with the data collection and the writing of an earlier version of this report.

\section{References}

[1]Microsimulator and Mesosimulator in AIMSUN 6 User's Manual, Draft version 2009 (TSS-Transport Simulation Systems, 2009)

[2]Burghout, Wilco.A note on the number of replication runs in stochastictraffic simulation models

[3]Electronic Statistics Textbook http://www.statsoft.com/textbook/distrib ution-tables/assessed at 20:30 2010-3004

[4]BassemYounes, Roundabouts vs. Intersections: The Tale of Three UAE Cities, A review of historic developments and current practice with an aerial photographic documentation.

[5] Wisconsin Department of Transportation,

http://www.dot.state.wi.us/safety/motori st/roaddesign/roundabouts/benefits.htm, assessed at 22:17 2010-28-04

[6]Roundabouts: An Informational Guide (FHWA-RD-00-067), (U.S Federal Highway Administration)

[7] Roundabout USA, http://www.roundaboutsusa.com/intro.ht ml, assessed at 22:26 2010-28-04

[8]Highway Capacity Manual, (Transportation research board, 2000)
[9]U.S
Federal
Highway

Administration, Traffic Signal Timing Manual, http://ops.fhwa.dot.gov/publications/f hwahop08024/chapter4.htm, assessed at 23:13 2010-28-04

[10] Community Planning Association of Idaho, http://compassidaho.org/, assessed at 4:00 2010-25-04 